\title{
Changes in technology and the effects on the utilization of manpower in South Africa
}

\author{
G.F. Jacobs \\ Professor, University of the Witwatersrand, \\ 1 Jan Smuts Ave., Johannesburg, 2001
}

Extracts from a speech by Professor G.F. Jacobs delivered to the National Congress for Manpower Utilization in South Africa

\section{Introduction}

The phenomenal acceleration of change in the world will be sketched and put into perspective. The reasons for the dramatic new developments in technology will be outlined, inter alia:

- Each discovery constitutes a building-block for subsequent discovery, hence growth in technology is not merely geometric, it is exponential.

- Research in technology is supported massively by organized businesses and by the state and is gaining further impetus all the time. Some $90 \%$ of the world's scientists who have ever lived and worked are alive and doing research now.

New technological developments will have a profound effect on job structures and manpower utilization. Some $80 \%$ of the jobs which will exist at the turn of this century are non-existent at the present time. Similarly, many skills which are now used will become completely obsolete during the next 20 years. South Africa is therefore entering the third major industrial revolution, namely, one centering upon improved technology and manpower utilization.

\section{Changes in technology in South Africa}

Changes in technology have taken place and will continue to take place in South Africa. Expansion of the manufacturing industry with which technology is most associated, mainly characterizes economic growth in South Africa over the last quarter of a century.

From 1950 to the mid ' 70 s, the real value-added in manufacturing grew at a rate appreciably higher than the growth rate in the GDP. The fastest rate of expansion in manufacturing took place from 1962-69 mainly as a result of a particularly rapid rise in capital inputs of $9,8 \%$ p.a. compared with an increase of only $5,3 \%$ in labour inputs. Owing to the continuing substitution of capital for labour, the capital/labour ratio increased sharply during the ' 70 s.

There is the example of the textile industry, the fourth largest employer of labour in South Africa, highly sensitive to competition, turning increasingly to mechanization and automated equipment. Where one loom was operated by one weaver, 16 per weaver is now common and the speed of production so much faster that large numbers of operators can be replaced.

A recent study in the engineering industry indicates that manufacture in the telephone switchgear industry is changing from mechanically to electronically operated switchgear, reducing labour by some $90 \%$.

The elimination of the compositor in the South African printing trade is another example: with new techniques, one employee can now replace 10 to 15 compositors. By $1976,40 \%$ of the sugar crop was mechanically loaded. The remarkable growth in the capital intensity of mining is reflected in the large increase in the capital/labour ratio in the industry of about $150 \%$ between 1950 and 1978 .

Electronic banking is one of the newest technologies presently being implemented on a wide scale in South Africa and is only one of many highly advanced techniques being considered or in the process of being applied in many sectors of the service and manufacturing industries. Petro-chemicals, iron and steel are further examples among the highly capital-intensive groups.

South Africa is obviously on the bandwagon. The important question is, why should it be so?

The entrepreneur in commerce and industry has his share of human hassles considerably exacerbated by rules and regulations affecting every single Black in employment and there is no doubt that the latter is a factor that frequently influences the decision to go for machines rather than men. Then again, the acute shortage of skilled labour and the consequent effect on wages is forcing many entrepreneurs to choose between mechanization and stagnation. On the wage front too, the fact that wage rates paid in South Africa must often satisfy overseas dicta, motivates employers to prefer machines to men.

Long runs of increased volume and of standard quality are other aims of mechanization, while the ubiquitous anticipation of lower costs and bigger profit is a constant spur.

In addition to these fairly well-grounded expectations of gain following on the increased use of machinery, one must bear in mind that this is the age of electronics, the legendary belief that the machine, the computer, and the automated production line will do everything not only bigger but also better. Technology has become a value in itself, a part of the culture of production, (opposed at the cost of being thought eccentric) almost a total ideology as powerful and persuasive as any other that history has known.

\section{Productivity growth}

Technical leadership rests with the 'best-practice' plants or firms and not with the average with the result that within any country or industry, there is a markedly wide spread in productivity performance. Some differences reflect variations in management or labour efficiency but generally, the high productivity plants have the most modern equipment and those with lower productivity have older equipment.

World productivity growth accelerated greatly in the post-war period, increasing more than 2,5 times as fast on average as in the eight decades $1870-1950$. The U.S.A. has lead in productivity for over 100 years, though since the war, other countries have exploited the opportunities of 'backwardness' and are catching up fast. A study for 
the early seventies for example, indicated that in 16 products out of 60 , Japanese productivity exceeded that of the U.S.A.

Long-term economic growth is primarily the result of the growth of technological knowledge, but the direction of growth is induced by demand, and the pace by the rate of investment. Some critics believe that decreasing returns are unavoidable because of trial and error, and because the size of the pool of technical skills to develop, diffuse and successfully apply new techniques is limited. However, technologically 'backward' countries, among which South Africa is included, have an enormous potential advantage in that they do not have to break new ground, they can imitate rather than innovate. One should however not exaggerate the ease of this process since known technology must be adapted to particular needs in terms of product-mix, resource endowments, labour skills and a host of other individual differences.

Productivity performance of economies is also highly dependent on the stock of 'educational capital'. The U.S.A. has held the lead in education as it has in productivity. Then there is the question of structural changes: countries which entered the post-war period with a large pool of underemployed labour in agriculture were able to enjoy structural changes favourable to growth.

One factor slowing productivity in the '70s has been the growth in regulations regarding the environment, pollution, safety and health. It is estimated that these reduced the growth of U.S.A. output by $0,3 \%$ in 1970 .

It has of course been observed that the optimum use of resources assumed by neoclassical growth may never be achieved in practice because methods of using equipment may well continue to be improved until the machine is scrapped and then the process starts all over again. This may have been responsible for the productivity slowdown in the '70s which is furthermore attributable to the following facts:

- The European countries and Japan were operating closer to best practice technology, which made productivity gains more difficult to obtain.

- The importance of the structural shift from agriculture and the gains from trade waned in importance.

- Various types of regulation and the increase in energy prices imposed constraints.

- Cyclical slack constrained productivity growth mainly by reducing the growth of the capital stock and the efficiency of resource allocation.

- There was a growing under-utilization of the labour supply.

In general, the basic 'supply' factors still seem to warrant future rates of productivity growth higher than pre-war experience, but if the climate of demand is weakened enough to lower investment incentive at a stage when technical pioneering and risktaking have to be faced, then the momentum of these economies could be considerably weakened.

\section{Applying technology in South Afrlca Introduction}

In spite of the advantages of technological imitation or innovation, the decision 'to mechanize or not to mechanize' in South Africa is not one that can be safely resolved by the cost accountant and the engineer alone. There are vast socio-political implications as well. South Africa, like other not-fully developed countries, has the problem of rising unemployment among the least advanced sector of its population of which it also forms by far the greatest proportion.

To compound the problem still further, South Africa is going through a period of acute skilled labour shortage.

\section{The labour scarcity problem}

Looking at our population as a whole, as far as Whites are concerned, the $0-4$ age group is now narrower than its superstructure which means that, barring immigration, there will be a decline in White manpower numbers over the next 20 years.

Asian manpower growth is still fairly high but diminishing. Coloured manpower is still expanding very rapidly and faster than population growth in aggregrate. The Black sector is the least advanced in the demographic cycle but is entering the phase of fertility declining faster than mortality.

It has furthermore been estimated that by the year $2000,51 \%$ of the labour force must be in White Collar occupations representing an addition of close on 3000000 people; $49 \%$ must be in Blue Collar jobs, in numbers, an addition of 2300000 workers.

The addition to the executive class of 200000 workers would have to be larger than the total of 170000 at work at present. The ranks of the higher skilled White Collar workers, inclusive of teachers, will have to be strengthened by more than twice the existing number.

There has been an obsolute decline in the number of Blue Collar semi-skilled and unskilled White workers over the last 20 years. Assuming that Whites in Blue Collar jobs remain constant, gross new entries required will be 3800 skilled and 3000 semi-skilled workers per year.

Furthermore, the introduction of technology as a national objective tends to exacerbate the problem since the dismissed unskilled worker is the least equipped for training or retraining.

\section{Unemployment}

In the present period of economic upswing, one hears less about the pool of unemployed Blacks and more about the scarcity of skilled workers, but they are there. To cater for new work-seekers, almost 6 million new job opportunities for Blacks alone will have to be created over the next 20 years -1500 new jobs daily at a cost of 15 million rand per working day, if calculated at a figure of R10 000 per job opportunity which is conservative now and way below what inflation can make it in 20 years' time.

Many observers believe that Government policy has caused too many workers to be replaced by machines and that the trend should be reversed. This policy also had made labour too expensive and capital too easy to obtain. It has encouraged capitalization through tax concessions and penalized the employment of labour through the red tape and inconvenience that surround the legal employment of Black labour. If present trends in capital/labour input continue, there will be a steady growth in the 
number unemployed each year to the year 2000 , the consequence of which is that some $35 \%$ of economically employable people, 6 million or so, (the vast majority Black) will not be provided for in the formal economic sector.

\section{Reaction to unemployment}

There is an increasing hostility among workers to unemployment and a trend towards 'institutionalized' opposition.

World-wide there is evidence of this and in South Africa the proposed establishment of the first trade union for the unemployed by the South African Allied Workers Union (SAAWU) possibly heralds a new era of organized confrontation. Of more immediate concern, is the attitude of the newly emerging Black Unions whose members are for the most part unskilled or semi-skilled and therefore those first affected by mechanization.

Some Industrial Conciliation Agreements with which Black Unions are associated are already including job protection clauses to cover inter alia retrenchment or redundancy. The aim is to raise the 'cost' of retrenchment or redundancy to the employer by introducing, e.g. the 'first in last out' principle, voluntary early retirement, retraining obligations, short-time or work-sharing alternatives, severance pay and long warning provisions.

Job creation will conceivably be the next step in trade union activity in this field which could mean Black Trade Unions seeking to share in management's power to 'hire and fire'.

Improved technology could therefore become a major factor exacerbating confrontation and conflict in the decades ahead.

\section{Self-fulfilment and technology}

The automated era is also associated with boredoin and lack of self-fulfilment for the individual. Sociologists have detected a swing away from material gain through higher incomes as adequate compensation for the loss of non-material satisfaction. The Protestant ethic of the intrinsic virtue of hard work and patient submission to the demands of one's occupation has taken a knock and more and more people are believing that work situations that conflict with personal convictions and convenience are too high a price to pay for material success. In consequence, the belief that technological advance is good so long as it leads to material advantage is no longer tenable.

Nuclear power is a case in point: in spite of its potential as a source of energy and substitute for oil and its many other attributes for alleviating some of the world's pressing material needs, governments are facing tremendous problems in its application because socially and morally it is deemed by many to be unacceptable. The Tavistock Institute of Human Relations' researches into coal mining found clear evidence that, for success, the demands of technology must be modified by relating people to tasks. Before the introduction of long-wall coal mining, small, self-selected groups of all-rounders, paid as a group, worked harmoniously and well without supervision. When three shifts, each devoted to specialized tasks, were introduced to meet the demands of new technology, team relations were far less effective and closer and more coercive supervision was required. The system was satisfac- torily revised to accommodate both human needs and the demands of increased efficiency.

The technology of the future will therefore have to concern itself more and more with workers' and society's reaction to its use, which is yet another piece to add to the as yet unfathomable puzzle of how to use men and machines in the best interests of all mankind.

\section{South Africa will increasingly use technology}

In spite of all the drawbacks, South Africa will increasingly turn to technology and modernize its technology mainly because:

- It's there.

- South Africa is among the technologically backward countries when compared with the U.S.A., Japan or Europe and has considerable lee-way to make up (55 man-hours to produce 1 vehicle in South Africa; 25 hours in Europe).

- Labour problems, including escalating wages and salaries, and artificial obstacles to the employment of Black labour, continue to influence entrepreneurs to prefer machines to men.

- South Africa's productivity is well below that of other Western countries, a state of affairs that can only be remedied by a combination of technological advance and the better deployment and use of a far better trained labour force.

Improved productivity accounts for some $70 \%$ of economic growth in the West: in South Africa it accounts for about $30 \%$. In a comparison of the average value of goods produced per capita (GNP over labour force) in a number of industrialized countries, South Africa is at the bottom of the poll:

$\begin{array}{ll}\text { West Germany } & \$ 26793 \\ \text { U.S.A. } & \$ 25566 \\ \text { France } & \$ 22446 \\ \text { Australia } & \$ 16995 \\ \text { U.K. } & \$ 12402 \\ \text { Italy } & \$ 12164 \\ \text { South Africa } & \text { R 4221 }\end{array}$

Our labour participation rate (i.e. our economically active population) at $41 \%$ is only slightly lower than the figure for developed countries: the solution therefore lies in using labour better, which means inter alia training them better before they are placed in employment.

\section{Training our labour}

Training over the next two decades will be influenced by the need for increased volume to meet increased demand and a change in content to meet the requirements of new technology. An added problem as far as South Africa is concerned is that the undeveloped, unskilled sector of our population cannot simply be trained to use technology; for a great number, their whole way of life, customs, values, habits of thought, ties of kindred and notions of obligation, authority, time and punctuality have to change if they are to serve the needs of a sophisticated economy using advanced technology.

So far as content is concerned, even if the content is geared to vocational purposes, needs are so varied that gaps are impossible to assess and it will fall on employers 
to fill them. This could mean that in-training schemes will include much more general education in the future which will pose problems in regard to the availability of suitable instructors.

Obsolescence among employees will increase in the 1990s, especially in the professional/specialist and managerial categories. Much of the impetus towards retraining will come from the employee, simply as a matter of survival. However, in many instances, the location of resources and facilities will often be beyond the individual's scope which once more places increasing responsibilities on the employer.

Other developments may be:

- The extended use of matrix organizations for managing complex development projects.

- Greater reliance on small groups for manufacturing and assembling intricate equipment which will mean more attention to the selection of compatible individuals.

- Greater emphasis on human relations skills in the general management function in the ' 90 s.

The latter will be the result of dealing with more sophisticated and highly educated groups of employees who will make greater demands in respect of personnel management techniques such as motivation, negotiation, performance appraisal and so on.

Formal training will be more prominent, thus higher initial qualifications will be required, followed by the mastery of a much wider range of knowledge.

The numbers involved and the variety of training demanded will lead to more substantial training facilities in terms of numbers employed and level of instruction expertise. This means that investment, that is money invested, in training and development must increase and will certainly rise further in the years ahead.

\section{The need for appropriate technology or finding the} right mix

Western technology as we know it, developed in countries with well-trained labour and we cannot have the one without the other.

What we do not want to do is to imitate blindly or go for capital intensity just because the Head Office in Texas or Germany insists on it because it works there. We have the crucial problems of raising efficiency and productivity while at the same time keeping a weather-eye on the pending unemployment storm. We must therefore aim to develop the right mix of appropriate technology and labour use to suit our circumstances and problems.

Even labour-intensive systems are not always simple and do not exclude the use of some technology but it should be appropriate. Appropriate technology has been described as 'technology which in the economic, social and other conditions under which it is applied gives the greatest contribution to development objectives'.

Thus though 'small' may not always be the ideal, and certainly is often inappropriate, the small business has significant value in certain circumstances. In the U.S.A. small industries employing less than 20 people added 7 million workers during the recession of 1971 to 1977 , or $66 \%$ of all new jobs created. Neither is 'big' necessarily all bad: expansion in the high technology industries in the
U.S.A. has led to the establishment of thousands of new small industries doing sub-contract work for the gargantuan multi-nationals. Japan saw the need for the subcontractor and chose South Korea, Taiwan and Hong Kong as suppliers - the latter has 35000 small industries, which account for $18 \%$ of its GDP.

The technology applied in each case should therefore be neither capital nor labour-orientated, but resourceintensive, i.e., technology based on the availability of certain resources, labour and capital.

We should begin to think 'South African' in the capital investment market, to use South African-made machines better designed and adapted to our problems. Much discarded technology may be improved for efficient operation in labour-intensive situations, for example, and in general, it would be well worth our while to encourage the establishment of an Appropriate Technology Research Institute and encourage Trade Unions to debate the question of long-term technological policy.

More and better education - and in the nature of things, it will be predominantly directed towards the Black labour force - is a prerequisite to more advanced technology. We must also adopt an informed attitude to increasingly sophisticated job fragmentation as an aid to easing the unemployment problem. We must encourage all forms of entrepreneurship. It has been suggested that Government regulations in regard to minimum standards restricts experimentation and the use of alternative methods. Any restriction on entrepreneural activity such as still applies to Black, Coloureds and Asians also discourages the application of technology, however simple, and the extra employment of people. These too, where they still exist, must go in their entirety. What is required is to extend the range of choices and to allow a wider range of standards and market patterns to co-exist.

A certain amount of planning even in a free enterprise economy is inevitable, even if it is only to plan to remove restricting rules and regulations. So let us aim to ask the right questions and work to find the true answers.

Above all, let us increasingly ensure a healthy exchange of views between those who propose investing in technology and those, the workers, who must use it and apply it. 